\title{
Central nervous system metastases and oligoprogression during treatment with tyrosine kinase inhibitors in oncogene-addicted non-small cell lung cancer: how to treat and when?
}

\author{
Janna Josephus Anna Oda Schoenmaekers ${ }^{1,2}$, Marthe Sentijna Paats ${ }^{3}$, Anne-Marie Clasina Dingemans ${ }^{1,2,3}$, \\ Lizza Elisabeth Lucia Hendriks ${ }^{1,2}$
}

${ }^{1}$ Department of Pulmonary Diseases, Maastricht University Medical Centre, Maastricht, The Netherlands; ${ }^{2}$ Department of Pulmonary Diseases GROW, School for Oncology and Developmental Biology, Maastricht University Medical Centre, Maastricht, The Netherlands; ${ }^{3}$ Department of Pulmonary Diseases, Erasmus Medical Centre, Rotterdam, The Netherlands

Contributions: (I) Conception and design: All Authors; (II) Administrative support: All Authors; (III) Provision of study materials or patients: All Authors; (IV) Collection and assembly of data: All Authors; (V) Data analysis and interpretation: All Authors; (VI) Manuscript writing: All authors; (VII) Final approval of manuscript: All authors.

Correspondence to: Prof. Anne-Marie Clasina Dingemans, MD, PhD. Department of Pulmonary Diseases, Erasmus Medical Centre, P.O. 2040, 3000

CA Rotterdam, The Netherlands. Email: a.dingemans@erasmusmc.nl.

\begin{abstract}
Up to $70 \%$ of non-small cell lung cancer (NSCLC) patients develop central nervous system (CNS) metastases during the course of their disease, especially those with oncogenic drivers treated with a first-generation tyrosine kinase inhibitor (TKI), because of the relatively poor CNS penetration. CNS metastases are associated with a negative impact on quality of life and survival. As, with the introduction of newer generation TKIs, the survival rates are increasing in this particular population, treatment and/ or prevention of CNS metastases becomes even more relevant and the TKI with the best CNS efficacy should be selected. Unfortunately, CNS efficacy data in clinical trials are not fully comparable. Furthermore, oligoprogression to the brain without extracranial progression regularly occurs in the oncogenic driver population and both local therapy and switch of systemic therapy are possible treatment options. However, the best order of systemic and local therapy is still not precisely known. In this narrative review, we will summarize incidence and treatment of CNS metastases in oncogene driven NSCLC, including the optimal treatment of CNS oligometastatic disease (synchronous as well as oligoprogressive).
\end{abstract}

Keywords: Non-small cell lung cancer (NSCLC); central nervous system metastases (CNS metastases); oligometastatic disease; tyrosine kinase inhibitors (TKIs)

Submitted Mar 20, 2020. Accepted for publication Jun 04, 2020.

doi: $10.21037 /$ tlcr-20-459

View this article at: http://dx.doi.org/10.21037/tlcr-20-459

\section{Introduction}

Central nervous system (CNS) metastases frequently occur in non-small cell lung cancer (NSCLC). Approximately $10-20 \%$ of patients with NSCLC present with CNS metastases at diagnosis, and about $40-70 \%$ will develop CNS metastases during the course of their disease (1-3). CNS metastases are a poor prognostic factor and have a negative impact on quality of life (QoL) (4).

Due to both increased screening for CNS metastases in almost all NSCLC disease stages [except the (very) early stages] (5-7), and improved NSCLC survival rates, the incidence of CNS metastases is increasing. Next to this, the detection of asymptomatic CNS metastases due to screening in otherwise non-metastatic patients can result in an increased incidence of CNS only metastases $(7,8)$. The widespread uptake of magnetic resonance imaging (MRI, advised in current guidelines) instead of computed tomography (CT) for CNS metastases screening probably 
results in an even higher incidence of CNS only metastases, as MRI is more sensitive than CT (9). A topic of discussion is the best sequence of treatments in patients with baseline asymptomatic CNS disease: local treatment (e.g., radiation) followed by systemic therapy, or systemic therapy with local treatment upon CNS progression $(7,8,10,11)$. A special category are those patients with oncogenic driven NSCLC. In general, the preferred treatment option for neurologically asymptomatic oncogene-addicted NSCLC patients [epidermal growth factor receptor (EGFR) mutation, rearrangements of anaplastic-lymphoma-kinase (ALK), ROS proto-oncogene 1 (ROS1), MET deregulation (amplification or MET exon 14 mutations), RET-fusions, $\mathrm{N}$ tropomyosin receptor kinase (NTRK) gene fusion, $B$-Raf proto-oncogene (BRAFv600E) mutation] is a tyrosine kinase inhibitor (TKI) $(5,7)$. An advantage of the next generation TKIs is the often superior CNS penetration rate compared with the first generation TKIs $(12,13)$. As the median overall survival (OS) of patients with EGFR or $A L K$ driven NSCLC has improved to more than 5 years it is expected that CNS metastases will become more prevalent in this group, and that patients will live longer with CNS metastases $(14,15)$. Therefore, the optimal treatment, and preferably even prevention, of CNS metastases is an important topic in current clinical trials enrolling patients with oncogene-addicted NSCLC. Historically, patients with CNS metastases were often not eligible for trial participation. Although symptomatic brain metastases (BM) and leptomeningeal metastases (LM) are still exclusion criteria in the majority of clinical trials, patients with asymptomatic or treated $\mathrm{BM}$ are increasingly eligible (16). However, interpretation of CNS related outcome measures of clinical trials is hampered by the lack of standardisation of imaging in these trials (modality, frequency) and by the fact that BM eligibility criteria differ between trials (e.g., untreated allowed or not, definition of stable BM). Moreover, patients were not always stratified according to presence of $\mathrm{BM}$, and outcome of this subgroup was rarely a prespecified endpoint (16). In addition, oligoprogression in the brain can occur during systemic treatment. Most trials did not specify which treatments were allowed while on study, and optimal therapy of CNS oligometastatic disease is largely unknown. This is especially relevant in patients with oncogene driven NSCLC who develop oligoprogressive disease in the brain, without extracranial progressive disease, while on TKI treatment.

In this narrative review, we will summarize incidence and treatment of CNS metastases in oncogene driven NSCLC, including the optimal treatment of all types of CNS oligometastatic disease (e.g., synchronous, metachronous, oligopersistent, oligoprogressive). We will focus mainly on phase III trials, except when no phase III data are available or phase I/II data have added value (e.g., specific CNS subgroup data).

\section{The incidence of CNS metastases and TKI options in oncogene driven NSCLC patients}

Oncogene-addicted NSCLC is characterized by a particularly high incidence of CNS metastases, with percentages reaching up to $70 \%$ for $\mathrm{BM}$ and $10 \%$ for $\mathrm{LM}$ during the course if the disease $(1,17-21)$.

\section{EGFR mutation}

The incidence of an activating EGFR mutation in lung cancer is about $10 \%$ in Caucasians and $50 \%$ in Asians (22). The incidence of $\mathrm{BM}$ at diagnosis ranges from $23-32 \%$ $(19,23,24)$. In a retrospective series it was shown that with the use of first generation EGFR-TKI (erlotinib and gefitinib) and second generation EGFR-TKI (in this series only dacomitinib evaluated) the cumulative incidence of $\mathrm{BM}$ increases over time, resulting in a 5 -year incidence of $53 \%$ (N=86 EGFR-mutated and $23 A L K$-rearranged NSCLC patients) (19).

Treatment options for metastatic EGFR-mutated NSCLC patients are first generation EGFR-TKI (erlotinib and gefitinib), second generation EGFR-TKI (afatinib, dacomitinib) and the third generation EGFR-TKI osimertinib (7). None of the pivotal EGFR-TKI trials on which approval was based for these EGFR-TKIs, mandated baseline CNS metastases screening. In the EURTAC trial (comparing erlotinib to platinum/gemcitabine or platinum/ docetaxel as first line treatment) (25), LUX-Lung 3 trial (comparing afatinib to cisplatin/pemetrexed) (26), LUXLung 7 trial (comparing afatinib to gefitinib) (27), AURA trial (comparing osimertinib to platinum-pemetrexed) (28) and FLAURA trial (comparing osimertinib to standard EGFR-TKI) (13) only asymptomatic stable BM were eligible. In the ARCHER trial (comparing dacomitinib to gefitinib as first line treatment) patients with known BM were excluded (29). The presence of BM was a stratification factor in the LUX-Lung 7, AURA and FLAURA trials $(13,27,28)$. BM specific outcomes were also reported for those three trials, with osimertinib having the highest intracranial objective response rate (icORR) 
and intracranial progression free survival (icPFS). None of the trials specified whether it was allowed to administer local treatment in a CNS oligoprogressive patient with continuation of the study drug. Detailed trial description and results are summarized in Table 1 .

\section{Translocation of the anaplastic lymphoma kinase gene}

The incidence of $A L K$ translocation in NSCLC patients is about $3-7 \%(32,33)$. The incidence of BM is about $20-40 \%$ at baseline (34-37). Under treatment with crizotinib, the first approved ALK-TKI, 51-72\% of patients developed BM. This high percentage can be explained by the poor CNS penetration of this drug $(1,38,39)$.

After crizotinib, several other next-generation ALKTKIs were approved, namely ceritinib, alectinib, brigatinib and lorlatinib (34-36,40).

Compared to EGFR-TKI trials, most ALK-TKI trials have intracranial responses as one of their endpoints.

A retrospective pooled analyses of the PROFILE 1005 and PROFILE 1007 trials (respectively a single arm phase II trial investigating the efficacy of crizotinib in previously treated $A L K$ rearranged NSCLC patients and a randomized phase III trial comparing crizotinib with chemotherapy in the same group of patients), showed that the CNS was the most common site of progression when on crizotinib treatment. Both trials included patients with asymptomatic or treated BM (pooled analysis: $31 \%$ with baseline BM of which $40 \%$ no prior brain irradiation), and baseline screening for BM was mandatory. In patients without BM at the start of crizotinib therapy $20 \%$ developed BM, with a median time to detection of 29.9 weeks. Next to this, CNS progression occurred in about $70 \%$ of patients that had baseline BM (20).

In contrast to the randomized phase III EGFR-TKI trials, the PROFILE 1007 and 1014, the ASCEND-4 and 5 trial, ALTA-1L trial, ALUR trial, ALEX trial as well as the lorlatinib trial mandated baseline CNS screening (34-37,41-43). In all of these trials, asymptomatic stable BM were eligible (34-37,40-43). Only in the PROFILE 1014 and in the ALUR trial the BM had to be locally treated. BM was a stratification factor in the eight studies mentioned above. For all these trials, BM specific outcomes were reported with brigatinib having the highest icORR (83\%). Patients with CNS only progression in the ALTA-1L trial, requiring local therapy such as stereotactic radiotherapy (SRT), were allowed to continue brigatinib after SRT (brigatinib mandatory paused during SRT) after discussion with the sponsor. Other trials did not allow local treatment for oligoprogression with afterwards continuation of the study drug. Detailed trial description and results are summarized in Table 2.

\section{Other molecular alterations; ROS1, MET, RET, NTRK, BRAF V600E}

ROS1 rearrangements occur in approximately $1-2 \%$ of NSCLC patients. Compared with $A L K$ rearrangements, patients with ROS1 rearrangements have a lower percentage of baseline BM (19\% vs. 39\%). ROS1-positive patients also had a significantly lower cumulative incidence of BM (34\% vs. $73 \%$ at 5 years). However, these are retrospective data without mandatory CNS metastases screening at baseline or standardized follow up imaging (44).

In a phase I-II trial analysing the efficacy of lorlatinib in treatment naive as well as pretreated NSCLC patients with a $R O S 1$ alteration $(\mathrm{N}=69), 57 \%$ of patients had $\mathrm{BM}$ at baseline. Screening for BM with MRI brain at baseline was mandatory. Asymptomatic treated BM, untreated BM as well as asymptomatic LM were eligible. The icOR was $64 \%$ in treatment naive patients and $50 \%$ in pretreated patients with crizotinib (45).

$M E T$ deregulation [amplification or exon 14 (METex14) skipping] is found in approximately $3-4 \%$ of NSCLC (46). The incidence of BM in this group is about $20 \%$ at baseline (47).

In a phase II trial analysing the efficacy of crizotinib in pretreated NSCLC patients with a ROS1 alteration or a MET deregulation (amplification or MET exon 14 mutations) $23 \%$ and $19 \%$ of patients had BM at baseline, respectively. Only patients with stable and treated BM were allowed. BM was not a stratification factor nor was BM specific outcome a prespecified endpoint. None of the $\mathrm{MET}^{+}$patients with BM responded (48). Results from another phase II trial analysing the efficacy of capmatinib in pretreated as well as in treatment naive NSCLC patients with a MET exon 14 skipping mutation are promising, with intracranial response observed in 54\% (7/13) of patients with $\mathrm{BM}$ at baseline. However, more data are awaited (49).

$B R A F-V 600 \mathrm{E}$ mutation is present in $1-2 \%$ of NSCLC. In the open label phase II trial analysing the efficacy of dabrafenib/trametinib in pretreated stage IV NSCLC patients with a $B R A F-\mathrm{V} 600 \mathrm{E}$ mutation, $1.8 \%$ of patients had BM at baseline. Of note, it was not mentioned whether screening for BM was mandatory. Asymptomatic or treated $\mathrm{BM}$ were eligible (50). In the same study an extra cohort 
Table 1 Summary CNS characteristics in pivotal phase II en III EGFR-TKI trials

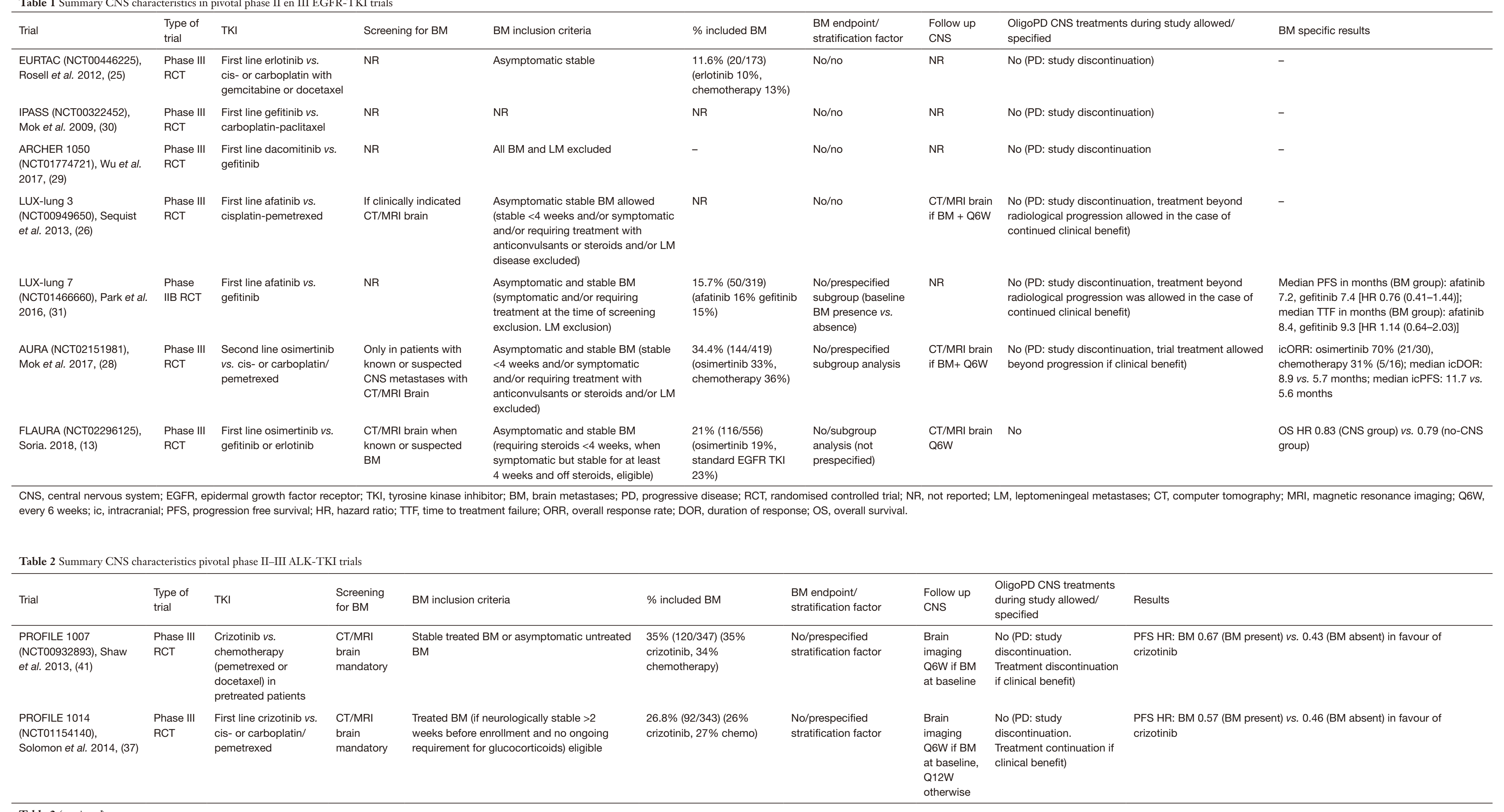




\begin{tabular}{|c|c|c|c|c|c|c|c|c|c|}
\hline Trial & $\begin{array}{l}\text { Type of } \\
\text { trial }\end{array}$ & TKI & $\begin{array}{l}\text { Screening } \\
\text { for BM }\end{array}$ & BM inclusion criteria & \% included BM & $\begin{array}{l}\text { BM endpoint/ } \\
\text { stratification factor }\end{array}$ & $\begin{array}{l}\text { Follow up } \\
\text { CNS }\end{array}$ & $\begin{array}{l}\text { OligoPD CNS treatments } \\
\text { during study allowed/ } \\
\text { specified }\end{array}$ & Results \\
\hline $\begin{array}{l}\text { ASCEND-4 } \\
\text { (NCT0182809), Soria } \\
\text { et al. 2017, (36) }\end{array}$ & $\begin{array}{l}\text { Phase III } \\
\text { RCT }\end{array}$ & $\begin{array}{l}\text { First line ceritinib vs. } \\
\text { cis- or carboplatin/ } \\
\text { pemetrexed }\end{array}$ & $\begin{array}{l}\text { Brain CT or } \\
\text { MRI }\end{array}$ & $\begin{array}{l}\text { Asymptomatic or stable CNS metastases } \\
\text { eligible (neurologically unstable or has } \\
\text { required increasing doses of steroids within } \\
\text { the } 2 \text { weeks prior to screening exclusion) }\end{array}$ & $\begin{array}{l}32 \%(121 / 376)(31 \% \\
\text { crizotinib, 33\% } \\
\text { chemotherapy) }\end{array}$ & $\begin{array}{l}\text { icORR, icDCR, icDOR } \\
\text { (secondary endpoints)/ } \\
\text { Yes }\end{array}$ & $\begin{array}{l}\text { If positive } \\
\text { at baseline } \\
\text { Q6W }\end{array}$ & No not allowed & $\begin{array}{l}\text { Ceritinib BM group: } 48 \% \text { ( } 15 / 31) \text { icPD only, } 42 \% \text { extracranial PD only } \\
\text { and } 10 \% \text { both. Ceritinib no BM group: } 30 \%(24 / 81) \text { icPD only, } 69 \% \\
\text { extracranial PD only, } 1 \% \text { both. Median PFS in months in BM group } 10.7 \\
\text { (ceritinib) vs. } 6.7 \text { (chemotherapy), icORR 46.3\% }\end{array}$ \\
\hline $\begin{array}{l}\text { ASCEND-5 } \\
\text { (NCT01828112), Shaw } \\
\text { et al. 2017, (42) }\end{array}$ & $\begin{array}{l}\text { Phase III } \\
\text { RCT }\end{array}$ & $\begin{array}{l}\text { Ceritinib vs. } \\
\text { pemetrexed or } \\
\text { docetaxel after } \\
\text { chemotherapy and } \\
\text { crizotinib }\end{array}$ & $\begin{array}{l}\text { Brain CT or } \\
\text { MRI }\end{array}$ & $\begin{array}{l}\text { Asymptomatic or stable CNS metastases } \\
\text { eligible (neurologically unstable or has } \\
\text { required increasing doses of steroids within } \\
\text { the } 2 \text { weeks prior to screening exclusion) }\end{array}$ & $\begin{array}{l}58 \%(134 / 231) \\
(57 \% \text { ceritinib, } 59 \% \\
\text { chemotherapy) }\end{array}$ & $\begin{array}{l}\text { icORR, icDCR, icDOR } \\
\text { (secondary endpoints)/ } \\
\text { yes }\end{array}$ & $\begin{array}{l}\text { If positive } \\
\text { at baseline }\end{array}$ & - & $\begin{array}{l}\text { Median PFS in months in BM group: } 4.4 \text { ceritinib, } 1.5 \text { chemotherapy. } \\
68 \% \text { had PD, } 51 \% \text { icPD only (21/41), } 41 \% \text { extracranial PD only, } 7 \% \\
\text { both. In no BM group: } 62 \% \text { had PD. } 15 \% \text { icPD only, } 85 \% \text { extracranial } \\
\text { PD only. } 35 \% \text { icOR. median icDOR } 6.9 \text { months }\end{array}$ \\
\hline $\begin{array}{l}\text { Lorlatinib } \\
\text { (NCTo1970865), } \\
\text { Solomon et al. 2018, (40) }\end{array}$ & Phase II & $\begin{array}{l}\text { First, or next line } \\
\text { lorlatinib }\end{array}$ & $\begin{array}{l}\text { MRl of the } \\
\text { brain }\end{array}$ & $\begin{array}{l}\text { Asymptomatic CNS metastases (including } \\
\text { patients controlled with stable or decreasing } \\
\text { steroid use within the last } 2 \text { weeks before } \\
\text { study entry) LM eligible }\end{array}$ & $\begin{array}{l}60 \%(166 / 275) \text { [Group } 1 \\
\text { treatment naive ALK+ 8/30 } \\
\text { (27\%). Group 2-5 ALK+ } \\
\text { with previous treatment } \\
67 \%(133 / 198)]\end{array}$ & $\begin{array}{l}\text { Primary endpoint: } \\
\text { intracranial tumour } \\
\text { response; secondary } \\
\text { endpoint: icDOR, CSF } \\
\text { concentration lorlatinib, } \\
\text { probability of CNS } \\
\text { progression/yes }\end{array}$ & $\begin{array}{l}\text { Brain MRI } \\
\text { Q6W }\end{array}$ & $\begin{array}{l}\text { No (PD: treatment } \\
\text { discontinuation. } \\
\text { Continuation if clinical } \\
\text { benefit allowed) }\end{array}$ & $\begin{array}{l}\text { IcORR group 1: 66.7\%, group 2-5: 63\%. Median time to first ic response } \\
\text { in months: group 1:2.0, group 2-5: 1.4. Median icDOR: group 1: NR, } \\
\text { group 2-5: 14.5 }\end{array}$ \\
\hline $\begin{array}{l}\text { ALTA-1L } \\
\text { (NCTo2737501), } \\
\text { Camidge et al. 2018, (35) }\end{array}$ & $\begin{array}{l}\text { Phase III } \\
\text { RCT }\end{array}$ & $\begin{array}{l}\text { First line brigatinib vs. } \\
\text { crizotinib }\end{array}$ & $\begin{array}{l}\text { MRl of the } \\
\text { brain }\end{array}$ & $\begin{array}{l}\text { Treated or neurologically stable for } 7 \text { days } \\
\text { before randomization (symptomatic CNS } \\
\text { metastases (BM or LM) at screening or } \\
\text { asymptomatic disease requiring an increasing } \\
\text { dose of corticicosteroids }<7 \text { days prior to } \\
\text { randomization exclusion) }\end{array}$ & $\begin{array}{l}\text { 29.5\% (81/275) [Brigatinib } \\
40 / 137(29 \%) \text {; Crizotinib } \\
41 / 138(30 \%)]\end{array}$ & $\begin{array}{l}\text { Secondary } \\
\text { endpoints: icORR, } \\
\text { icPFS/prespecified } \\
\text { stratification factor (BM } \\
\text { present or absent) }\end{array}$ & $\begin{array}{l}\text { Brain MRI } \\
\text { Q8W }\end{array}$ & $\begin{array}{l}\text { Patients with CNS } \\
\text { lesions requiring local } \\
\text { radiotherapy such as SRS } \\
\text { are allowed to continue } \\
\text { the study drug after } \\
\text { appropriate interruption }\end{array}$ & $\begin{array}{l}\text { ICORR: brigatinib } 83 \% \text {, crizotinib } 33 \% \text {. } 12 \text {-month survival without icPD in } \\
\text { BM group: brigatinib } 67 \% \text {, crizotinib } 21 \%\end{array}$ \\
\hline $\begin{array}{l}\text { ALEX (NCT02075840), } \\
\text { Peters et al. 2017, (34) }\end{array}$ & $\begin{array}{l}\text { Phase III } \\
\text { RCT }\end{array}$ & Alectinib vs. crizotinib & $\begin{array}{l}\mathrm{CT} / \mathrm{MRI} \\
\text { brain }\end{array}$ & $\begin{array}{l}\text { Treated/untreated BM eligible. Previous CNS } \\
\text { RT allowed if completed } \geq 14 \text { days before } \\
\text { enrollment }\end{array}$ & $\begin{array}{l}\text { 40.3\% (122/303) [Alectinib } \\
64 / 152(42.1 \%) \text {, Crizotinib } \\
58 / 151(38.4 \%)]\end{array}$ & $\begin{array}{l}\text { CNS efficacy endpoints } \\
\text { (icPFS, time to } \\
\text { CNS progression, } \\
\text { icORR, icDOR/CNS } \\
\text { metastases prespecified } \\
\text { stratification factor }\end{array}$ & $\begin{array}{l}\text { Brain } \\
\text { imaging } \\
\text { Q8W }\end{array}$ & No & $\begin{array}{l}\text { Patients BM group: CNS progression without prior non-CNS PD } \\
\text { crizotinib 56.9\%, alectinib 18.8\%; non-CNS progression without prior } \\
\text { CNS PD crizotinib 24.1\% alectinib } 17.2 \% \text {; death without prior CNS or } \\
\text { non-CNS PD crizotinib 6.9\% Alectinib 10.9\%. Patients no BM group: } \\
\text { CNS progression without prior non-CNS PD crizotinib 37.6\% alectinib } \\
6.8 \% \text {; non-CNS progression without prior CNS PD crizotinib 20.4\% } \\
\text { alectinib } 28.4 \% \text {; death without prior CNS or non-CNS PD crizotinib 5.4\% } \\
\text { alectinib 4.5\% }\end{array}$ \\
\hline
\end{tabular}


was analysed with NSCLC $B R A F-\mathrm{V} 600 \mathrm{E}$ treatment naive patients, $5.6 \%$ of patients had BM at baseline (51). BM specific outcome was not a prespecified endpoint. The 3 included patients with BM had stable disease as best intracranial response $(51,52)$.

NTRK rearrangements occur in up to $3 \%$ of NSCLC patients (53). In the entrectinib phase 1 and 2 trial, $22 \%$ of patients had BM at baseline with a mandatory baseline BM screening. Patients with stable asymptomatic BM were eligible. IcORR, icDOR, icPFS were prespecified secondary endpoints (54). The larotrectinib phase I and II trials showed an $8 \%$ incidence of $\mathrm{BM}$ at baseline. However, screening for CNS metastases at baseline was not mandatory and the group of patients consisted of a heterogeneous population of solid tumours including pediatric patients. Patients with asymptomatic treated and untreated BM were eligible. Of the three patients with measurable baseline BM, one had icCR, one icPR and one icSD (55).

RET rearrangements occur in 1-2\% of NSCLC patients. Incidence of BM in RET-rearranged NSCLC at baseline is $25 \%$, with a lifetime incidence of $46 \%$. CNS metastases seem to have a good response to treatment with pralsetinib and selpercatinib however, data is still very limited and more extensive data will follow $(56,57)$.

Detailed trial description and results are summarized in Table 3.

\section{Oligometastatic disease}

Different types of oligometastatic disease exist. All are relevant in the treatment of patients with an oncogenic driver and CNS metastases. The different types of oligometastases are summarized below, and put into context regarding CNS oligometastatic disease in patients with an oncogenic driver.

Oligometastatic disease is defined as a limited number of metastases. Two small randomized clinical trials showed improved survival when radical local therapy was added to standard systemic therapy for synchronous oligometastatic NSCLC, not progressing on induction systemic treatment $(58,59)$. Different types of oligometastatic disease (e.g., synchronous, metachronous, oligopersistent, oligoprogressive) could represent different prognoses and possibly also different treatment scenarios. Recently, the European Society for Radiotherapy and Oncology (ESTRO) together with the European Organisation for Research and Treatment of Cancer (EORTC) developed a proposal for characterization and classification of oligometastatic disease (60). Furthermore, the EORTC lung cancer group provided a detailed definition plus staging consensus for synchronous oligometastatic NSCLC (61).

De novo oligometastatic disease (first time diagnosis of oligometastatic disease) can be defined as synchronous oligometastatic disease ( $\leq 6$ months between primary cancer diagnosis and oligometastatic disease diagnosis) or metachronous oligometastatic disease $(>6$ months between primary cancer diagnosis and oligometastatic disease diagnosis).

\section{Synchronous and metachronous CNS oligometastases in patients with an oncogenic driver}

To the best of our knowledge, there is very limited data on the percentage of patients with an oncogenic driver and synchronous or metachronous CNS oligometastases. A phase III randomised controlled trial (RCT), comparing first line gefitinib to gefitinib with pemetrexed-carboplatin in EGFR mutated NSCLC patients showed that $4.3 \%$ of enrolled patients had oligometastases to the brain at baseline. However, this study had no mandatory screening of the CNS at baseline and the true percentage of CNS oligometastatic patients is not known (62). Most data are derived from CNS oligoprogression during TKI treatment, as is discussed below.

\section{CNS oligoprogression during TKI treatment}

Oligoprogression is defined as development of metachronous oligometastatic disease in patients under active systemic treatment. This type of oligometastatic disease is mainly prevalent in patients with oncogene driven NSCLC treated with targeted therapy. For TKIs with poor CNS penetration, oligometastatic disease in the brain is found in up to $38 \%$ of patients. In a post hoc analysis of the PROFILE 1014 trial intracranial progression without extracranial progression in the intention to treat population occurred in $24 \%$ of crizotinib patients and $10 \%$ of chemotherapy patients. This was in patients with treated $\mathrm{BM}$ respectively $38 \%$ vs. $23 \%$ and in patients without $\mathrm{BM}$ $19 \%$ vs. $6 \%$ (63). In a retrospective series of 21 crizotinibtreated patients, $38 \%$ developed oligoprogression in the brain without extracranial progression (64). In the ASCEND-4 trial $48 \%$ of the patients with baseline BM had CNS progression as first site of progression, compared with $30 \%$ in the group without baseline BM. It was not 
Table 3 Summary CNS characteristics pivotal phase I and II trials ROS1/MET/BRAF V600E/NTRK

\begin{tabular}{|c|c|c|c|c|c|c|c|c|c|}
\hline Trial & Phase & TKI & $\begin{array}{l}\text { Screening } \\
\text { for BM }\end{array}$ & In- or exclusion & $\%$ included BM & $\begin{array}{l}\text { BM is endpoint/stratification } \\
\text { factor }\end{array}$ & $\begin{array}{l}\text { Follow up } \\
\text { CNS }\end{array}$ & $\begin{array}{l}\text { OligoPD CNS } \\
\text { continues in study } \\
\text { (yes/no) }\end{array}$ & Results \\
\hline $\begin{array}{l}\text { Lorlatinib (NCT01970865), Shaw } \\
\text { et al. 2019, (45) }\end{array}$ & $\begin{array}{l}\text { Phase I-II } \\
\text { (ROS1 alteration) }\end{array}$ & $\begin{array}{l}\text { Lorlatinib in treatment naive patients, disease } \\
\text { progression after at least } 1 \text { ROS } 1 \text { inhibitor } \\
\text { therapy or any number of previous therapies }\end{array}$ & MRI brain & $\begin{array}{l}\text { Asymptomatic treated or } \\
\text { untreated CNS metastases } \\
\text { eligible. Asymp LM eligible }\end{array}$ & $57 \%(39 / 69)$ & $\begin{array}{l}\text { Primary objective ic tumour } \\
\text { response; secondary } \\
\text { objective icDOR, time to } \\
\text { icPD/yes }\end{array}$ & $\begin{array}{l}\text { Brain } \\
\text { imaging } \\
\text { Q6W }\end{array}$ & $\begin{array}{l}\text { PD: treatment } \\
\text { discontinuation. } \\
\text { Continuation allowed } \\
\text { beyond progression }\end{array}$ & $\begin{array}{l}\text { Ic responses: TKI naive; } 11 \text { pts with baseline BM. } \\
45 \% \text { CR, } 18 \% \text { PR, } 18 \% \text { SD, } 18 \% \text { PD. Previous } \\
\text { treatment with crizotinib only; } 24 \text { pts with baseline } \\
\text { BM. 38\% CR, } 13 \% \text { PR, } 25 \% \text { SD, 8\% PD }\end{array}$ \\
\hline $\begin{array}{l}\text { METROS (NCT02499614), Landi } \\
\text { et al. 2019, (48) }\end{array}$ & $\begin{array}{l}\text { Phase II } \\
\text { (ROS1 or MET } \\
\text { alterations) }\end{array}$ & Crizotinib in pretreated patients & NR & Stable and treated BM & $\begin{array}{l}\text { ROS1 23\% (6/26), } \\
\text { MET 19\% (5/26) }\end{array}$ & No/no & $\begin{array}{l}\text { Brain } \\
\text { imaging } \\
\text { Q8W }\end{array}$ & No & $\begin{array}{l}\text { Baseline BM: } 6 \text { ROS1; } 2 \text { CR, } 4 \text { SD, } 3 \text { only } \\
\text { intracranial PD (50\%). } 5 \text { MET; } 2 \text { PD, } 3 \text { SD }\end{array}$ \\
\hline $\begin{array}{l}\text { Dabrafenib/trametinib } \\
\text { (NCT01336634), Planchard et al. } \\
\text { 2016, (50) }\end{array}$ & $\begin{array}{l}\text { Phase II } \\
\text { (BRAF V600E) }\end{array}$ & $\begin{array}{l}\text { Dabrafenib plus trametinib in previously } \\
\text { treated patients }\end{array}$ & NR & $\begin{array}{l}\text { Asymptomatic, untreated, } \\
\text { measured }<1 \mathrm{~cm} \text { eligible. } \\
\text { Treated BM, clinically and } \\
\text { radiologically stable } 3 \text { weeks } \\
\text { after local therapy }\end{array}$ & $1.8 \%(1 / 57)$ & No/no & NR & No & $\begin{array}{l}\text { ic response: SD. No patients with new BM as part } \\
\text { of their progression }\end{array}$ \\
\hline $\begin{array}{l}\text { Dabrafenib/trametinib } \\
\text { (NCT01336634), Planchard et al. } \\
\text { 2017, (51) }\end{array}$ & $\begin{array}{l}\text { Phase II } \\
\text { (BRAF V600E) }\end{array}$ & $\begin{array}{l}\text { Dabrafenib plus trametinib after previously } \\
\text { untreated patients }\end{array}$ & NR & $\begin{array}{l}\text { Asymptomatic, untreated, } \\
\text { measured }<1 \mathrm{~cm} \text { eligible. } \\
\text { Treated BM, clinically and } \\
\text { radiologically stable } 3 \text { weeks } \\
\text { after local therapy }\end{array}$ & $5.6 \%(2 / 36)$ & No/no & NR & No & IC response: SD \\
\hline $\begin{array}{l}\text { Entrectinib (NCT02097810, } \\
\text { NCT02568267, EudraCT 2012- } \\
\text { o00148-88), Doebele et al. 2020, } \\
\text { (54) }\end{array}$ & $\begin{array}{l}\text { Phase I and II } \\
\text { (NTRK) }\end{array}$ & Entrectinib in previous treated solid tumours & MRI or $\mathrm{CT}$ & $\begin{array}{l}\text { Controlled asymptomatic CNS } \\
\text { involvement allowed }\end{array}$ & $22 \%(12 / 54)$ & $\begin{array}{l}\text { Secondary endpoints: ic } \\
\text { response, ic DOR, icPFS/yes }\end{array}$ & $\begin{array}{l}\text { Brain } \\
\text { imaging } \\
\text { Q8W }\end{array}$ & No & $\begin{array}{l}\text { BM at baseline group: } 6 / 12(50 \%) \text { PR, } 4 / 12(33 \%) \\
\text { SD. } 17 / 54 \text { CNS progression event. Median time to } \\
\text { progression } 17 \text { months }\end{array}$ \\
\hline
\end{tabular}

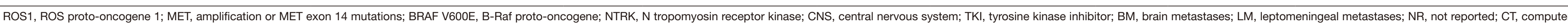

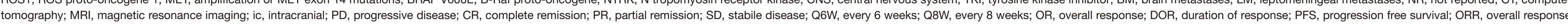
rate. 
reported if there was a difference between patients with or without previously radiotherapy to the brain (36). In the ASCEND-5 trial 51\% of the patients with baseline BM had intracranial progressive disease as first site of progression compared with $15 \%$ in the group without baseline BM (42). A retrospective Swiss cohort study analysing 50 EGFR T790M-positive NSCLC patients treated with osimertinib showed that $17 \%$ of patients progressed in the brain of whom $83 \%$ had oligoprogression (65). Similar data were reported for the FLAURA trial, in which $13 \%$ of osimertinib treated patients developed oligoprogression to the brain only (abstract only data). In the ALEX trial, CNS only progression (without non-CNS progression, analysed with a competing risk analysis) was significantly less frequent at 12 months in the alectinib arm compared with the crizotinib arm, both in radiotherapy pretreated $\mathrm{BM}$ as well as untreated $\mathrm{BM}(8.6 \%$ vs. $50.4 \%$, and $20.5 \%$ vs. $62.5 \%$, respectively (66). Similar results were found for brigatinib in the ALTA-1L trial. The 1-year cumulative incidence of intracranial progression without prior systemic progression for brigatinib $v s$. crizotinib was $12 \%(95 \% \mathrm{CI}$, 6-20\%) vs. 23\% (95\% CI, 15-31\%), respectively (35).

\section{CNS oligopersistent disease}

The last subtype of oligometastatic disease is oligopersistent disease, reflecting persistent non-progressive oligometastases under active systemic treatment. Data for oncogene driver CNS oligopersistent disease do not exist to the best of our knowledge.

These definitions are important because the prognosis and the treatment scenarios could be different between these entities (60). Furthermore, the underlying molecular mechanisms might differ between the oligometastatic entities.

\section{Molecular analysis of CNS metastases}

The question whether CNS metastases harbor distinct genetic alterations beyond those observed in primary tumors has not been definitively addressed. Data with whole-exome sequencing in 86 patient-matched BM (including 38 NSCLC patients) reported $53 \%$ of cases with potentially clinically informative alterations in $\mathrm{BM}$ that were not detected in the matched primary tumor sample (67). Interestingly, upon comparison of samples obtained from multiple different BM from the same patient, most anatomically distinct BM were found to share virtually all actionable driver alterations (29 of 30 , in a total of seven patients) $(67,68)$.

However, these findings have a number of technical limitations such as limited genomic characterisation and are yet to be supported by clinical evidence. On the other hand, overall response rate (ORR) to targeted therapies in molecularly defined NSCLC patients are typically similar in CNS and extra-CNS disease, arguing for fewer molecular discordances between the primary tumor and CNS metastases, at least for actionable mutations (18). Furthermore, recent insights into LM biology have shown that LM might have different molecular alterations compared to solid BM. In particular, LM have been found to be enriched in EGFR, MET, and tumor protein p53 (TP53) mutations, whereas they rarely harbor KRAS alterations $(7.7 \%)$ compared to other solid metastases from $\operatorname{NSCLC~(69,70).~}$

In oncogene-addicted NSCLC, isolated CNS progression is common especially in patients treated with $1^{\text {st }}$ or $2^{\text {nd }}$ generation TKIs as is described above (18). Although this is most likely related to insufficient blood-brain barrier (BBB) penetration of TKIs (71), the development of secondary resistance mutations or histologic transformation should also be considered as a potential cause of disease progression, as is most often the case for extracranial progression. The presence of the oncogenic driver mutation in brain $v s$. extracranial metastases or the primary tumor differs greatly across studies. Small case series have investigated the concordance of EGFR mutation status between primary tumors and matched CNS metastases. Discordance rates between 0 and $32 \%$ have been reported (72). It was also shown that 3 out of 24 patients $(12.5 \%)$ with both surgically resected $\mathrm{BM}$ and primary NSCLC, had evidence of histologic transformation in BM (73). Genomic profiling on tissue obtained from a progressing lesion to detect an acquired resistance to any TKI is considered the gold standard to determine the cause of resistance to the TKI. However, studies have shown that analysis of CNS metastases fails in up to $25 \%$ of the cases (74). Furthermore, in most patients with isolated CNS progression obtaining a tissue biopsy is not expedient due to the potential risk of neurological complications. Circulating tumor DNA (ctDNA) has emerged as a minimally-invasive tool, especially in the case of difficult-to-biopsy lesions or insufficient tissue material $(75,76)$. It is well established that oncogenic drivers and resistance mutations can be detected in ctDNA in both plasma and cerebrospinal fluid (CSF) with high 
sensitivity and specificity $(76,77)$. However, in case of oligoprogression in the $\mathrm{CNS}$, the $\mathrm{BBB}$ might reduce the presence of ctDNA in the bloodstream as has been reported by Aldea et al. who showed that the detection rate of ctDNA was significantly lower in NSCLC patients with isolated CNS progression compared with patients with extra-CNS progression (52\% and $84 \%$ respectively, $\mathrm{P}<0.00001)$ (78). Since classic TKI resistance mechanisms, i.e., the T790M-mutation in EGFR mutated NSCLC, develop under selective pressure of EGFR-TKI treatment and given the fact that the $\mathrm{BBB}$ reduces the penetration of TKIs into the CNS, it has been stated these mechanisms of resistance would normally not be detected in tumor cells from the CNS (79). Nevertheless, there are reports where mutation analysis was performed on malignant cells present in the CNS and where the T790M mutation was detected (80). Therefore, analysing ctDNA in the CSF seems to provide a valid alternative to detect genomic alterations of LM and CSF ctDNA may also represent the molecular status of intracranial lesions (81).

\section{CNS penetration rate TKI}

Despite favourable intracranial response rates with the current first line EGFR- and ALK-TKIs administered in standard daily doses [up to $91 \%$ for osimertinib and $81 \%$ for alectinib, respectively $(12,13)]$, a significant number of patients will still develop isolated CNS progression as is described above $(82,83)$ despite significant $\mathrm{BBB}$ penetration. At present, our understanding of $\mathrm{BBB}$ penetrating capabilities of TKIs has improved considerably. The key molecular properties that influence the BBB are: the $\mathrm{P}$-glycoprotein (PGP) or breast cancer resistance protein (BCRP) substrate nature of the TKIs, their molecular weight, polar surface area (PSA) and lipophilicity index $(\log \mathrm{P})(84,85)$.

For first generation EGFR-TKI erlotinib and gefitinib, the $\mathrm{BBB}$ permeation or diffusion rates are $2.8-5.1 \%$ and $1.1 \%$, respectively $(21,86,87)$. The CSF penetration rates of erlotinib and gefitinib are $2.77 \pm 0.45$ and $1.13 \pm 0.36$, respectively, and CSF concentration rates are $28.7 \pm$ 16.8 and $3.7 \pm 1.9 \mathrm{ng} / \mathrm{mL}$, respectively (87-89). Hence, compared to gefitinib, the pharmacokinetic parameters of erlotinib appear more favourable. There is preclinical evidence that afatinib is an effective treatment for CNS metastases despite incomplete penetration of the $\mathrm{BBB}$ $(27,90)$ even after resistance to erlotinib or gefitinib has developed (91). Nevertheless, in LUX-LUNG 7 the magnitude of PFS improvement with afatinib vs. gefitinib was similar to that observed in patients with or without BM (31). For dacomitinib, another second-generation EGFR-TKI, clinical data on the effect on CNS metastasis is not well known since these patients were specifically excluded from the ARCHER 1050 study (29) and another study of dacomitinib in patients with progressive BM (NCT02047747) was terminated early.

Although the third generation EGFR-TKI osimertinib is a substrate for both PGP and BCRP efflux transporters, in vitro data have shown that unlike other EGFR-TKIs, the penetration rate of osimertinib is sufficient to overcome this efflux (92). Preclinical evidence in nonhuman primates shows that osimertinib has greater penetration of the BBB and higher brain exposure compared with other EGFRTKIs (92). In a PET study of healthy human volunteers, a single microdose of $\left[{ }^{11} \mathrm{C}\right]$ osimertinib demonstrated rapid and widespread distribution in the brain (93).

CSF penetration rate for crizotinib is only $0.0026 \%$ (19). For patients with $A L K$-rearranged NSCLC, next generation ALK inhibitors were designed to cross the BBB more efficiently than crizotinib and to achieve higher concentration in the CSF, thus offering a prominent ability to control CNS spread. This effect was accomplished by reduction of their molecular weight, increasing lipophilicity and changing the number of available hydrogen bond donors. Next generation ALK-TKI are therefore more promising in the treatment of BM. CSF penetration rate for second generation ALK-TKIs alectinib and ceritinib are $87 \%$ and $15 \%$, respectively (19). Paired CSF and systemic plasma samples analysis for alectinib demonstrated the linear relationship between CSF and free alectinib plasma concentrations (94). Brain responses have also been described after progression on crizotinib (95). The phase II ASCEND-7 study showed that ceritinib was active in ALK-positive patients with BM and LM regardless of prior treatment that included brain radiotherapy and prior ALK inhibitor therapy, radiotherapy alone, or prior sole ALK inhibitor therapy (96). Moreover, the selective, potent, brain-penetrant 3rd-generation ALKTKI lorlatinib showed clinically meaningful antitumor activity in both intracranial and extracranial compartments, in the post $2 \mathrm{nd}$-gen ALK-TKI setting. Despite the development of TKIs with better penetration of the BBB, progression or the development of CNS metastases still occurs frequently. To increase the permeability and CSF concentrations of TKIs, their administration in "pulsatile" high-doses has been investigated $(97,98)$. Furthermore, 
because of oral administration of TKIs, the intrapatient and interpatient exposure is highly variable and is affected by many factors, such as concomitant use of food and herbs. Food-drug interactions are capable of altering the systemic bioavailability and pharmacokinetics (PK) of these drugs (99). Therefore, in suboptimally dosed patients, increasing the maximum concentration of drug in plasma blood and the CNS, e.g., dosing with food (99) or combining with other drugs such as proton pump inhibitors (100) might be necessary. Last, in patients with suboptimal TKI concentrations, therapeutic adherence should be evaluated, and if necessary, new instructions should be given.

\section{Treatment options of CNS oligoprogression}

Clinical controversies in the optimal management of oligoprogressive disease, especially CNS oligoprogression, remain due to a lack of prospective data comparing different treatment strategies (101). Furthermore, as is described above, a clear definition of oligometastatic disease has only been proposed recently (60). Whether to treat disease with a change of systemic therapies or to offer local ablative treatment [i.e., most often stereotactic radiosurgery/ therapy (SRS/SRT), if possible] is still a matter of debate. Ablative treatments are able to effectively target resistant clones regardless of the mutational genotype or load. Therefore, this may be an attractive additional treatment option for patients presenting with oligoprogression before considering a change in systemic treatment. In practice, the conventional approach to patients presenting with oligoprogressive disease varies depending on a number of patient factors including the site of oligoprogression, the number, size and location of the CNS metastases (i.e., option to offer local ablative therapy) and of course the type (BBB penetration or not) and number of subsequent lines of systemic treatments available.

Recently, the response assessment in neuro-oncology (RANO)-BM working group has made a framework for the conduction and evaluation of clinical trials for patients in the context of CNS metastases in order to generate more robust data on CNS activity than it has in the past (101). It is important to use bicompartmental efficacy assessments, specific protocol wording to record best overall, best CNS, and best systemic responses and duration of benefit, and to clarify permitted actions at CNS progression $v s$. non-CNS progression (102).

\section{Local treatment options (radiotherapy/surgery)}

Local treatment options for BM consist of whole-brain radiotherapy (WBRT), SRS/SRT (further described as SRT) or surgical resection. These treatments can relieve intracranial symptoms and improve intracranial local control. However, all of these treatments have a risk of neurotoxicity, which can occur months after treatment (e.g., symptomatic radiation necrosis after SRT, cognitive decline after WBRT) $(103,104)$. Therefore, especially WBRT with its late neurocognitive toxicity is being more and more avoided in patient with an oncogenic driver. Surgery is usually only used in case of a patient with neurological symptoms due to mass effect. Surgery would also be interesting to evaluate CNS resistance mechanisms in patients with CNS oligoprogression while on TKI treatment. To the best of our knowledge, no high-level data exist on this topic.

Furthermore, for each patient with CNS metastases, the risk-benefit ratio of local therapy, and the alternative of systemic treatment with CNS efficacy should be evaluated (i.e., alectinib after progression on crizotinib in $A L K$-rearranged NSCLC patients or osimertinib after progression on erlotinib in EGFR-mutated NSCLC patients with a T790M mutation), taking into account the expected long term OS.

Broadly speaking, three situations can occur in driver mutated patients with CNS metastases eligible for a TKI. The first is a treatment naive patient with CNS metastases. The second is a patient treated with a TKI, developing oligoprogression in the brain. The last is a patient who develops simultaneous CNS and extra-CNS progression under TKI treatment.

By giving upfront TKIs and postponing radiotherapy to a TKI naive patient, the possible neurotoxicity could be delayed, which is important because of the increasing survival in this patient group. Furthermore, by upfront TKI, the extracranial disease will be controlled as early as possible. However, icORR is not $100 \%$, and patients can develop neurological symptoms due to their progressing CNS metastases. A multi-institutional retrospective analysis including EGFR-mutated NSCLC, TKI naive patients who developed BM, demonstrated that the use of upfront EGFR-TKI, and deferral of radiotherapy was associated with inferior OS. SRT followed by EGFRTKI resulted in the longest survival. However, this study is limited by its retrospective nature with inherent 
selection bias (94). A systematic review and meta-analysis evaluated whether upfront cranial radiotherapy improved intracranial disease control and survival in EGFR-mutant NSCLC with BM compared with TKIs alone. The study included 12 observational non-comparative studies, of which 6 prospective and 6 retrospective. Upfront cranial radiotherapy resulted in similar icORR, improved fourmonth icPFS and improved two-year OS, but caused more neurological adverse events compared with TKIs alone (105). To complicate matters, preclinical studies demonstrate a possible synergistic effect of TKIs given concurrently with radiation, but toxicity data of this concurrent strategy is largely lacking in daily clinical practice (106-108). A retrospective analysis showed that in patients with $E G F R$ and $A L K$ concomitant radiotherapy (SRT) and TKI seemed to positively affect OS with limited toxicity in selected patients (93). A systematic review concluded that there are arguments that TKI combined with WBRT could be given safely (however high-level evidence is lacking, and evidence was only found for erlotinib, gefitinib and icotinib, while data on other TKI or SRT were largely lacking) (109). When WBRT was given combined with SRT and concurrent EGFRTKI neurotoxicity increased (95). A few studies looked specifically at isolated intracranial oligoprogression. One retrospective study assessed the clinical efficacy of continuing an EGFR-TKI following radiotherapy after isolated CNS failure. The overall median PFS was 2.6 months with a median extracranial PFS of 5.6 months. Al the patients were evaluated for their evaluable lesions with imaging approximately every 2 months (110). Another retrospective analysis including CNS oligoprogressive $A L K$ or EGFR positive NSCLC patients treated with crizotinib or erlotinib respectively, investigated the benefits of local ablative treatment (included SRT and WBRT) to the CNS metastases. The median PFS (calculated from time of initiation of targeted therapy to first progression of disease) was 7.1 months (111). A retrospective study evaluated continuing crizotinib after radiotherapy (4 patients WBRT and 3 patients SRT) to isolated CNS metastases in 7 ALK NSCLC patients. The median PFS, from time of start crizotinib to first progression, was 5.5 months. All these patients continued to receive crizotinib for at least 4 months without disease progression (64). The previously mentioned pooled analysis of the PROFILE trials showed data of 34 patients, developing intracranial progression only and continued the use of crizotinib. About $80 \%$ of these patients received radiotherapy. The median treatment duration post progression was 19.3 weeks (20). As the majority of these studies were retrospective, and most of them only included patients treated with a first generation TKI, the optimal treatment strategy or sequence of the combination of (newer) TKIs and local therapy remains unclear, especially in those with a non-EGFR driver. In 2018, an EORTC lung cancer group survey among 462 physicians, showed that management of CNS metastases was indeed highly variable in Europe, showing the lack of high-level evidence regarding management of CNS metastases in patients with an oncogenic driver (8).

Future research should focus on the best order of systemic and local treatment; upfront cranial radiation or upfront TKI with salvage radiotherapy for oligoprogressive CNS disease. Trials currently ongoing and investigating this issue are a study of osimertinib and SRT $v s$. osimertinib alone for BM in EGFR positive NSCLC patients (NCT03769103); The OUTRUN trial, a phase II trial of osimertinib with or without SRT for EGFR positive NSCLC patients with BM (NCT03497767); the BRART trial, investigating the role of brain radiotherapy in patients with asymptomatic BM in the era of targeted therapy for NSCLC (NCT04193007); a phase III RCT investigating the efficacy of EGFR-TKI alone in EGFRpositive NSCLC patients $v s$. EGFR-TKI concurrent with WBRT (NCT02714010) and the Cambridge Brain Mets Trial, investigating whether administration of a low dose of targeted radiotherapy during afatinib treatment could increase the concentration of drug penetration into the BM (NCT02768337). Furthermore, in both TKI treatment naive patients with CNS disease, as in those with oligoprogressive CNS disease during TKI treatment the use of concurrent treatment strategies should be further evaluated. The EORTC survey of Levy et al. showed that depending on the type of TKI, up to $44 \%$ of physicians continued the TKI concurrent with cranial irradiation. For those discontinuing the TKI, time of, and reasons for discontinuation were variable (8). As these patients often have a long survival, long-term toxicity and QoL should be taken into account as well. Currently, a multicenter phase IV trial is ongoing, with as primary endpoint neurotoxicity, investigating whether TKIs can be given safely concurrent with SRT or WBRT in CNS oligoprogressive patients treated with a TKI (NTR6707). Another ongoing phase I trial in EGFR positive NSCLC patients with 1-10 BM ( $3 \mathrm{~cm}$ or less in greatest dimension) is investigating whether macro BM can be controlled with SRT concurrent with osimertinib to control micro BM and avoid WBRT to 
prevent cognitive decline (NCT03535363).

\section{Systemic treatment options}

Although attractive in many cases, the utility of conventional systemic therapy in the treatment of $\mathrm{BM}$ has historically been limited due to poor penetration across the BBB and blood-tumor barrier (112). Traditional clinical trials for systemic therapies have excluded patients with symptomatic or uncontrolled BM due to these challenges with CNS penetration (113). The development of new generation TKI with better CNS permeability also challenges the concept of upfront radiotherapy for CNS metastases as is also described above, offering both better efficacy and tolerability. Moreover, in retrospective series, patients with EGFR mutations and $A L K$ rearrangements who continue TKI beyond first progression, especially those with isolated CNS progression, have been suggested to have a survival benefit when treated with local CNS therapy, compared with patients who stop TKI $(111,114,115)$. Tumour flare, which can occur with the interruption of TKI, again in particular in patients with CNS disease, may play a role in this $(111,116)$. Furthermore, the third generation EGFRTKIs (osimertinib, rociletinib, and AZD3759) have been proved in preclinical and early clinical studies to penetrate the BBB more effectively than previous generation EGFRTKIs, and overcome their most common mechanisms of resistance $(92,117)$.

As mentioned before, "pulsatile" high-doses of TKI to increase the permeability and CSF concentrations have been investigated. Currently this concept is used in series to treat $\mathrm{BM}$ and $\mathrm{LM}$ that developed during standard dose EGFR-TKI. Erlotinib has better BBB penetration than afatinib or gefitinib, and dose-intensification strategies have been proven to improve CNS diffusion of TKI $(87,88)$. Prospective studies have confirmed the feasibility of TKI dose increase in clinical practice, notably for erlotinib and osimertinib $(98,118)$. In small series, high-dose EGFR-TKIs and switch of EGFR-TKI treatment have been described as treatment options. In a phase I prospective study, median neurological PFS and OS with high-dose gefitinib (750$1,000 \mathrm{mg}$ ) were reported as 2.3 and 3.5 months, respectively $(\mathrm{N}=7)(119)$.

Data on treatment outcomes of oncogene-addicted NSCLC patients diagnosed with LM during or after first generation TKI treatment are scarce. Several case studies have reported successful treatment of LM with highdose pulsatile administration of erlotinib (120); however, a retrospective study of patients with LM refractory to standard dose EGFR-TKIs found no difference in the median OS between patients treated with high-dose erlotinib $(\mathrm{N}=12)$ and those treated with standard-dose EGFR-TKIs ( $\mathrm{N}=23 ; 6.2$ vs. 5.9 months, respectively); median time to CNS progression was 2.3 months (121). In the BLOOM trial, a phase 1 study, the antitumor efficacy, PK and safety of osimertinib $160 \mathrm{mg}$ once daily in patients with EGFR-mutated NSCLC and LM whose disease had progressed on previous EGFR-TKI therapy (98). Confirmed CSF response was observed in $28 \%$ of patients during treatment. However, the definition of CNS response was complete CSF clearance of tumor cells while more recent studies have defined partial CSF response as a $\geq 50 \%$ reduction in CSF tumor cells because CSF clearance is seldom achieved (77). Moreover, in the BLOOM study, the data showed no positive effect of prior brain radiotherapy on LM response to osimertinib. LM ORR was $55 \%$ in patients who received prior brain radiotherapy compared with $57 \%$ in patients who did not receive prior brain radiotherapy (98).

Besides dose-intensification strategies, several studies have looked at combining EGFR-TKI with vascular endothelial growth factor directed monoclonal antibody therapy (122). The BELIEF trial was an international, multicenter, single-arm phase II trial of 109 treatmentnaïve, advanced or metastatic, EGFR-mutant, lung adenocarcinoma patients treated with the combination erlotinib and bevacizumab (123). Thirty-seven patients (34\%) harbored T790M mutations and 21 (19\%) had BM; the median PFS was 13.2 months overall and 8.8 months for patients with BM (123). The efficacy of this combination in the BM population does not appear to be superior to standard EGFR TKI therapy (27), however only 21 patients with BM were included in the BELIEF trial. One of the greatest concerns with bevacizumab use among brain metastatic patients has been CNS hemorrhage. While CNS hemorrhage carries high morbidity and mortality, the incidence of CNS hemorrhage among bevacizumabtreated patients is less than $0.2 \%$ (124). Ongoing studies are investigating the combination of osimertinib and bevacizumab in EGFR-mutant NSCLC with BM (NCT02971501).

When all TKI options are exhausted, platinum-doublet chemotherapy is the therapy of choice (7). Intracranial response rates are relatively low compared with TKI (125), and to the best of our knowledge no data exist regarding intracranial efficacy of platinum-doublet chemotherapy in 
patients with CNS oligoprogression. Up to date there is no evidence that combining or continuing TKI treatment with platinum-based chemotherapy after CNS progression improves intracranial response rates or OS.

\section{Conclusions}

CNS metastases are common in oncogene addicted NSCLC patients. Incidence increases during the course of the disease, especially with first generation TKI treatment, due to the relatively low CNS penetration rate. A significant percentage of TKI treated patients will have CNS oligoprogression, also when treated with next generation TKIs. Unfortunately, most clinical trials did not specify endpoints nor treatment options regarding CNS oligoprogression. Furthermore, CNS efficacy data in clinical trials are not fully comparable, because imaging, eligibility criteria and endpoints were not standardised. Future research is necessary to investigate the best CNS treatment strategy in oncogene driven patients with CNS metastases. This is especially the case for patients with CNS oligoprogression, as trial data are largely lacking, and data available come from retrospective series. Future research with standardisation of clinical trials in the context of CNS metastases is necessary to understand the best order of systemic treatment and local treatment strategies. Both the EORTC oligometastatic consensus papers as well as the RANO proposal could be of help in standardizing clinical trials. Last, special attention should be paid to longterm toxicity, as the majority of oncogene driven NSCLC patients can have a prolonged survival, even in the presence of CNS metastases.

\section{Acknowledgments}

Funding: None.

\section{Footnote}

Provenance and Peer Review: This article was commissioned by the Guest Editors (Silvia Novello, Francesco Passiglia) for the series "Looking for Chimeras in NSCLC: Widen Therapeutic Options Targeting Oncogenic Fusions" published in Translational Lung Cancer Research. The article was sent for external peer review organized by the Guest Editors and the editorial office.

Conflicts of Interest: All authors have completed the
ICMJE uniform disclosure form (available at http:// dx.doi.org/10.21037/tlcr-20-459). The series "Looking for Chimeras in NSCLC: Widen Therapeutic Options Targeting Oncogenic Fusions" was commissioned by the editorial office without any funding or sponsorship. MSP reports consulting fees from Lilly, Roche, and Takeda, outside the submitted work; AMCD reports grants from Bristol-Myers-Squibb, personal fees from Roche, BristolMyers-Squibb, Eli Lily, Takeda, and Boehringer Ingelheim, non-financial support from Abbvie, outside the submitted work; LELH reports receiving other fees from Boehringer Ingelheim for advisory board, other fees from BMS for travel support and advisory board, other fees from Roche for travel support and advisory board, grants from Roche and Boehringer Ingelheim, other fees from AstraZeneca for mentorship program with key opinion leaders, personal fees from Quadia for educational webinars, grants from Astra Zeneca, other fees from Lilly, Roche, Pfizer and Takeda for advisory board, other fees from MSD as speaker and advisory board, outside the submitted work. The other author has no conflicts of interest to declare.

Ethical Statement: The authors are accountable for all aspects of the work in ensuring that questions related to the accuracy or integrity of any part of the work are appropriately investigated and resolved.

Open Access Statement: This is an Open Access article distributed in accordance with the Creative Commons Attribution-NonCommercial-NoDerivs 4.0 International License (CC BY-NC-ND 4.0), which permits the noncommercial replication and distribution of the article with the strict proviso that no changes or edits are made and the original work is properly cited (including links to both the formal publication through the relevant DOI and the license). See: https://creativecommons.org/licenses/by-nc-nd/4.0/.

\section{References}

1. Huber RM, Hansen KH, Paz-Ares Rodriguez L, et al. Brigatinib in Crizotinib-Refractory ALK+ NSCLC: 2-Year Follow-up on Systemic and Intracranial Outcomes in the Phase 2 ALTA Trial. J Thorac Oncol 2020;15:404-15.

2. Moro-Sibilot D, Smit E, de Castro Carpeno J, et al. Nonsmall cell lung cancer patients with brain metastases treated with first-line platinum-doublet chemotherapy: Analysis from the European FRAME study. Lung Cancer 2015;90:427-32. 
3. Yawn BP, Wollan PC, Schroeder C, et al. Temporal and gender-related trends in brain metastases from lung and breast cancer. Minn Med 2003;86:32-7.

4. Roughley A, Damonte E, Taylor-Stokes G, et al. Impact of Brain Metastases on Quality of Life and Estimated Life Expectancy in Patients with Advanced Non-Small Cell Lung Cancer. Value Health 2014;17:A650.

5. Ettinger et al. NCCN guidelines version 3.2020 NonSmall Cell Lung Cancer 2020. Available online: https:// www.nccn.org/professionals/physician_gls/pdf/nscl.pdf

6. Postmus PE, Kerr KM, Oudkerk M, et al. Early and locally advanced non-small-cell lung cancer (NSCLC): ESMO Clinical Practice Guidelines for diagnosis, treatment and follow-up. Ann Oncol 2017;28:iv1-iv21.

7. Planchard D, Popat S, Kerr K, et al. Metastatic non-small cell lung cancer: ESMO Clinical Practice Guidelines for diagnosis, treatment and follow-up. Ann Oncol 2018;29:iv192-iv237.

8. Levy A, Faivre-Finn C, Hasan B, et al. Diversity of brain metastases screening and management in nonsmall cell lung cancer in Europe: Results of the European Organisation for Research and Treatment of Cancer Lung Cancer Group survey. Eur J Cancer 2018;93:37-46.

9. Schoenmaekers J, Hofman P, Bootsma G, et al. Screening for brain metastases in patients with stage III nonsmall-cell lung cancer, magnetic resonance imaging or computed tomography? A prospective study. Eur J Cancer 2019;115:88-96.

10. Nabors et al. NCCN Guidelines Version 1.2020 Central Nervous System Cancers 2020 (updated March 10, 2020) Available online: https://www.nccn.org/professionals/ physician_gls/pdf/cns.pdf

11. Magnuson WJ, Lester-Coll NH, Wu AJ, et al. Management of Brain Metastases in Tyrosine Kinase Inhibitor-Naive Epidermal Growth Factor ReceptorMutant Non-Small-Cell Lung Cancer: A Retrospective Multi-Institutional Analysis. J Clin Oncol 2017;35:1070-7.

12. Hida T, Nokihara $H$, Kondo $M$, et al. Alectinib versus crizotinib in patients with ALK-positive non-small-cell lung cancer (J-ALEX): an open-label, randomised phase 3 trial. Lancet 2017;390:29-39.

13. Soria JC, Ohe Y, Vansteenkiste J, et al. Osimertinib in Untreated EGFR-Mutated Advanced Non-Small-Cell Lung Cancer. N Engl J Med 2018;378:113-25.

14. Lin JJ, Cardarella S, Lydon CA, et al. Five-Year Survival in EGFR-Mutant Metastatic Lung Adenocarcinoma Treated with EGFR-TKIs. J Thorac Oncol 2016;11:556-65.

15. Duruisseaux M, Besse B, Cadranel J, et al. Overall survival with crizotinib and next-generation ALK inhibitors in ALK-positive non-small-cell lung cancer (IFCT-1302 CLINALK): a French nationwide cohort retrospective study. Oncotarget 2017;8:21903-17.

16. McCoach CE, Berge EM, Lu X, et al. A Brief Report of the Status of Central Nervous System Metastasis Enrollment Criteria for Advanced Non-Small Cell Lung Cancer Clinical Trials: A Review of the ClinicalTrials.gov Trial Registry. J Thorac Oncol 2016;11:407-13.

17. Remon J, Le Rhun E, Besse B. Leptomeningeal carcinomatosis in non-small cell lung cancer patients: A continuing challenge in the personalized treatment era. Cancer Treat Rev 2017;53:128-37.

18. Remon J, Besse B. Brain Metastases in Oncogene-Addicted Non-Small Cell Lung Cancer Patients: Incidence and Treatment. Front Oncol 2018;8:88.

19. Rangachari D, Yamaguchi N, VanderLaan PA, et al. Brain metastases in patients with EGFR-mutated or ALKrearranged non-small-cell lung cancers. Lung Cancer 2015;88:108-11.

20. Costa DB, Shaw AT, Ou SH, et al. Clinical Experience With Crizotinib in Patients With Advanced ALKRearranged Non-Small-Cell Lung Cancer and Brain Metastases. J Clin Oncol 2015;33:1881-8.

21. Heon S, Yeap BY, Lindeman NI, et al. The impact of initial gefitinib or erlotinib versus chemotherapy on central nervous system progression in advanced non-small cell lung cancer with EGFR mutations. Clin Cancer Res 2012;18:4406-14.

22. Midha A, Dearden S, McCormack R. EGFR mutation incidence in non-small-cell lung cancer of adenocarcinoma histology: a systematic review and global map by ethnicity (mutMapII). Am J Cancer Res 2015;5:2892-911.

23. Iuchi T, Shingyoji $M$, Itakura $M$, et al. Frequency of brain metastases in non-small-cell lung cancer, and their association with epidermal growth factor receptor mutations. Int J Clin Oncol 2015;20:674-9.

24. Hendriks LE, Smit EF, Vosse BA, et al. EGFR mutated non-small cell lung cancer patients: more prone to development of bone and brain metastases? Lung Cancer 2014;84:86-91.

25. Rosell R, Carcereny E, Gervais R, et al. Erlotinib versus standard chemotherapy as first-line treatment for European patients with advanced EGFR mutation-positive non-small-cell lung cancer (EURTAC): a multicentre, open-label, randomised phase 3 trial. Lancet Oncol 2012;13:239-46.

26. Sequist LV, Yang JC, Yamamoto N, et al. Phase III study 
of afatinib or cisplatin plus pemetrexed in patients with metastatic lung adenocarcinoma with EGFR mutations. J Clin Oncol 2013;31:3327-34.

27. Schuler M, Wu YL, Hirsh V, et al. First-Line Afatinib versus Chemotherapy in Patients with Non-Small Cell Lung Cancer and Common Epidermal Growth Factor Receptor Gene Mutations and Brain Metastases. J Thorac Oncol 2016;11:380-90.

28. Mok TS, Wu YL, Ahn MJ, et al. Osimertinib or PlatinumPemetrexed in EGFR T790M-Positive Lung Cancer. N Engl J Med 2017;376:629-40.

29. Wu YL, Cheng Y, Zhou X, et al. Dacomitinib versus gefitinib as first-line treatment for patients with EGFRmutation-positive non-small-cell lung cancer (ARCHER 1050): a randomised, open-label, phase 3 trial. Lancet Oncol 2017;18:1454-66.

30. Mok TS, Wu YL, Thongprasert S, et al. Gefitinib or carboplatin-paclitaxel in pulmonary adenocarcinoma. $\mathrm{N}$ Engl J Med 2009;361:947-57.

31. Park K, Tan EH, O'Byrne K, et al. Afatinib versus gefitinib as first-line treatment of patients with EGFR mutationpositive non-small-cell lung cancer (LUX-Lung 7): a phase 2B, open-label, randomised controlled trial. Lancet Oncol 2016;17:577-89.

32. Soda M, Choi YL, Enomoto M, et al. Identification of the transforming EML4-ALK fusion gene in non-small-cell lung cancer. Nature 2007;448:561-6.

33. Koivunen JP, Mermel C, Zejnullahu K, et al. EML4-ALK fusion gene and efficacy of an ALK kinase inhibitor in lung cancer. Clin Cancer Res 2008;14:4275-83.

34. Peters S, Camidge DR, Shaw AT, et al. Alectinib versus Crizotinib in Untreated ALK-Positive Non-Small-Cell Lung Cancer. N Engl J Med 2017;377:829-38.

35. Camidge DR, Kim HR, Ahn MJ, et al. Brigatinib versus Crizotinib in ALK-Positive Non-Small-Cell Lung Cancer. N Engl J Med 2018;379:2027-39.

36. Soria JC, Tan DSW, Chiari R, et al. First-line ceritinib versus platinum-based chemotherapy in advanced ALKrearranged non-small-cell lung cancer (ASCEND-4): a randomised, open-label, phase 3 study. Lancet 2017;389:917-29.

37. Solomon BJ, Mok T, Kim DW, et al. First-line crizotinib versus chemotherapy in ALK-positive lung cancer. N Engl J Med 2014;371:2167-77.

38. Metro G, Tazza M, Matocci R, et al. Optimal management of ALK-positive NSCLC progressing on crizotinib. Lung Cancer 2017;106:58-66.

39. Griesinger F, Roeper J, Pottgen C, et al. Brain metastases in ALK-positive NSCLC - time to adjust current treatment algorithms. Oncotarget 2018;9:35181-94.

40. Solomon BJ, Besse B, Bauer TM, et al. Lorlatinib in patients with ALK-positive non-small-cell lung cancer: results from a global phase 2 study. Lancet Oncol 2018;19:1654-67.

41. Shaw AT, Kim DW, Nakagawa K, et al. Crizotinib versus chemotherapy in advanced ALK-positive lung cancer. $\mathrm{N}$ Engl J Med 2013;368:2385-94.

42. Shaw AT, Kim TM, Crino L, et al. Ceritinib versus chemotherapy in patients with ALK-rearranged nonsmall-cell lung cancer previously given chemotherapy and crizotinib (ASCEND-5): a randomised, controlled, openlabel, phase 3 trial. Lancet Oncol 2017;18:874-86.

43. Novello S, Mazieres J, Oh IJ, et al. Alectinib versus chemotherapy in crizotinib-pretreated anaplastic lymphoma kinase (ALK)-positive non-small-cell lung cancer: results from the phase III ALUR study. Ann Oncol 2018;29:1409-16.

44. Gainor JF, Tseng D, Yoda S, et al. Patterns of Metastatic Spread and Mechanisms of Resistance to Crizotinib in ROS1-Positive Non-Small-Cell Lung Cancer. JCO Precis Oncol 2017;2017:10.1200/PO.17.00063.

45. Shaw AT, Solomon BJ, Chiari R, et al. Lorlatinib in advanced ROS1-positive non-small-cell lung cancer: a multicentre, open-label, single-arm, phase 1-2 trial. Lancet Oncol 2019;20:1691-701.

46. Awad MM, Oxnard GR, Jackman DM, et al. MET Exon 14 Mutations in Non-Small-Cell Lung Cancer Are Associated With Advanced Age and Stage-Dependent MET Genomic Amplification and c-Met Overexpression. J Clin Oncol 2016;34:721-30.

47. Digumarthy SR, Mendoza DP, Zhang EW, et al. Clinicopathologic and Imaging Features of NonSmall-Cell Lung Cancer with MET Exon 14 Skipping Mutations. Cancers (Basel) 2019;11:2033.

48. Landi L, Chiari R, Tiseo M, et al. Crizotinib in METDeregulated or ROS1-Rearranged Pretreated NonSmall Cell Lung Cancer (METROS): A Phase II, Prospective, Multicenter, Two-Arms Trial. Clin Cancer Res 2019;25:7312-9.

49. Garon EB, Heist RS, Seto T, et al. Capmatinib in METex14-mutated (mut) advanced non-small cell lung cancer (NSCLC): Results from the phase II GEOMETRY mono-1 study, including efficacy in patients (pts) with brain metastases (BM). AACR; 27-28 April 2020. Abstract CT082.

50. Planchard D, Besse B, Groen HJM, et al. Dabrafenib 
plus trametinib in patients with previously treated BRAF(V600E)-mutant metastatic non-small cell lung cancer: an open-label, multicentre phase 2 trial. Lancet Oncol 2016;17:984-93.

51. Planchard D, Smit EF, Groen HJM, et al. Dabrafenib plus trametinib in patients with previously untreated BRAF(V600E)-mutant metastatic non-small-cell lung cancer: an open-label, phase 2 trial. Lancet Oncol 2017;18:1307-16.

52. Planchard D, Brown KH, Kim DW, et al. Osimertinib Western and Asian clinical pharmacokinetics in patients and healthy volunteers: implications for formulation, dose, and dosing frequency in pivotal clinical studies. Cancer Chemother Pharmacol 2016;77:767-76.

53. Vaishnavi A, Capelletti M, Le AT, et al. Oncogenic and drug-sensitive NTRK1 rearrangements in lung cancer. Nat Med 2013;19:1469-72.

54. Doebele RC, Drilon A, Paz-Ares L, et al. Entrectinib in patients with advanced or metastatic NTRK fusionpositive solid tumours: integrated analysis of three phase 1-2 trials. Lancet Oncol 2020;21:271-82.

55. Hong DS, DuBois SG, Kummar S, et al. Larotrectinib in patients with TRK fusion-positive solid tumours: a pooled analysis of three phase 1/2 clinical trials. Lancet Oncol 2020;21:531-40.

56. Gainor JF, Lee DH, Curigliano G; et al. Clinical activity and tolerability of BLU-667, a highly potent and selective RET inhibitor, in patients (pts) with advanced RETfusion+ non-small cell lung cancer (NSCLC). J Clin Oncol 2019;37:abstr 9008.

57. Drilon A, Oxnard G, Wirth L, et al. Registrational results of LIBRETTO-001: A phase 1/2 trial of LOXO-292 in patients with RET fusion-positive lung cancers. J Thorac Oncol 2019;14:S6-7.

58. Iyengar P, Wardak Z, Gerber DE, et al. Consolidative Radiotherapy for Limited Metastatic Non-Small-Cell Lung Cancer: A Phase 2 Randomized Clinical Trial. JAMA Oncol 2018;4:e173501.

59. Gomez DR, Tang C, Zhang J, et al. Local Consolidative Therapy Vs. Maintenance Therapy or Observation for Patients With Oligometastatic Non-Small-Cell Lung Cancer: Long-Term Results of a Multi-Institutional, Phase II, Randomized Study. J Clin Oncol 2019;37:1558-65.

60. Guckenberger M, Lievens Y, Bouma AB, et al. Characterisation and classification of oligometastatic disease: a European Society for Radiotherapy and Oncology and European Organisation for Research and Treatment of Cancer consensus recommendation. Lancet
Oncol 2020;21:e18-28.

61. Dingemans AC, Hendriks LEL, Berghmans T, et al. Definition of Synchronous Oligometastatic Non-Small Cell Lung Cancer-A Consensus Report. J Thorac Oncol 2019;14:2109-19.

62. Noronha V, Patil VM, Joshi A, et al. Gefitinib Versus Gefitinib Plus Pemetrexed and Carboplatin Chemotherapy in EGFR-Mutated Lung Cancer. J Clin Oncol 2020;38:124-36.

63. Solomon BJ, Cappuzzo F, Felip E, et al. Intracranial Efficacy of Crizotinib Versus Chemotherapy in Patients With Advanced ALK-Positive Non-Small-Cell Lung Cancer: Results From PROFILE 1014. J Clin Oncol 2016;34:2858-65.

64. Takeda M, Okamoto I, Nakagawa K. Clinical impact of continued crizotinib administration after isolated central nervous system progression in patients with lung cancer positive for ALK rearrangement. J Thorac Oncol 2013;8:654-7.

65. Schmid S, Klingbiel D, Aeppli S, et al. Patterns of progression on osimertinib in EGFR T790M positive NSCLC: A Swiss cohort study. Lung Cancer 2019;130:149-55.

66. Gadgeel S, Peters S, Mok T, et al. Alectinib versus crizotinib in treatment-naive anaplastic lymphoma kinase-positive $(\mathrm{ALK}+)$ non-small-cell lung cancer: CNS efficacy results from the ALEX study. Ann Oncol 2018;29:2214-22.

67. Brastianos PK, Carter SL, Santagata S, et al. Genomic Characterization of Brain Metastases Reveals Branched Evolution and Potential Therapeutic Targets. Cancer Discov 2015;5:1164-77.

68. Suh JH, Kotecha R, Chao ST, et al. Current approaches to the management of brain metastases. Nat Rev Clin Oncol 2020;17:279-99.

69. Li Y, Liu B, Connolly ID, et al. Recurrently Mutated Genes Differ between Leptomeningeal and Solid Lung Cancer Brain Metastases. J Thorac Oncol 2018;13:1022-7.

70. Ying S, Ke H, Ding Y, et al. Unique genomic profiles obtained from cerebrospinal fluid cell-free DNA of nonsmall cell lung cancer patients with leptomeningeal metastases. Cancer Biol Ther 2019;20:562-70.

71. Jackman DM, Holmes AJ, Lindeman N, et al. Response and resistance in a non-small-cell lung cancer patient with an epidermal growth factor receptor mutation and leptomeningeal metastases treated with high-dose gefitinib. J Clin Oncol 2006;24:4517-20.

72. Berghoff AS, Bartsch R, Wohrer A, et al. Predictive 
molecular markers in metastases to the central nervous system: recent advances and future avenues. Acta Neuropathol 2014;128:879-91.

73. Jiang $M$, Zhu X, Han X, et al. Histologic transformation of non-small-cell lung cancer in brain metastases. Int J Clin Oncol 2019;24:375-84.

74. Tredan O, Wang Q, Pissaloux D, et al. Molecular screening program to select molecular-based recommended therapies for metastatic cancer patients: analysis from the ProfiLER trial. Ann Oncol 2019;30:757-65.

75. Lindeman NI, Cagle PT, Aisner DL, et al. Updated Molecular Testing Guideline for the Selection of Lung Cancer Patients for Treatment With Targeted Tyrosine Kinase Inhibitors: Guideline From the College of American Pathologists, the International Association for the Study of Lung Cancer, and the Association for Molecular Pathology. J Thorac Oncol 2018;13:323-58.

76. Rolfo C, Mack PC, Scagliotti GV, et al. Liquid Biopsy for Advanced Non-Small Cell Lung Cancer (NSCLC): A Statement Paper from the IASLC. J Thorac Oncol 2018;13:1248-68.

77. Xu Y, Hu M, Zhang M, et al. Prospective study revealed prognostic significance of responses in leptomeningeal metastasis and clinical value of cerebrospinal fluid-based liquid biopsy. Lung Cancer 2018;125:142-9.

78. Aldea M, Hendriks L, Mezquita L, et al. Circulating Tumor DNA Analysis for Patients with OncogeneAddicted NSCLC With Isolated Central Nervous System Progression. J Thorac Oncol 2020;15:383-91.

79. Shingyoji M, Kageyama H, Sakaida T, et al. Detection of epithelial growth factor receptor mutations in cerebrospinal fluid from patients with lung adenocarcinoma suspected of neoplastic meningitis. J Thorac Oncol 2011;6:1215-20.

80. Kuiper JL, Hendriks LE, van der Wekken AJ, et al. Treatment and survival of patients with EGFRmutated non-small cell lung cancer and leptomeningeal metastasis: A retrospective cohort analysis. Lung Cancer 2015;89:255-61.

81. Li N, Liu Y, Duan J, et al. Prognostic significance of molecular characteristics of cerebrospinal fluid for nonsmall cell lung cancer patients with leptomeningeal metastasis. Thorac Cancer 2019;10:1673-82.

82. Nishio M, Nakagawa K, Mitsudomi T, et al. Analysis of central nervous system efficacy in the J-ALEX study of alectinib versus crizotinib in ALK-positive non-small-cell lung cancer. Lung Cancer 2018;121:37-40.

83. Reungwetwattana T, Nakagawa K, Cho BC, et al. CNS Response to Osimertinib Versus Standard Epidermal
Growth Factor Receptor Tyrosine Kinase Inhibitors in Patients With Untreated EGFR-Mutated Advanced NonSmall-Cell Lung Cancer. J Clin Oncol 2018. [Epub ahead of print]. doi: 10.1200/JCO.2018.78.3118.

84. Di L, Rong H, Feng B. Demystifying brain penetration in central nervous system drug discovery. Miniperspective. J Med Chem 2013;56:2-12.

85. Gottesman MM, Fojo T, Bates SE. Multidrug resistance in cancer: role of ATP-dependent transporters. Nat Rev Cancer 2002;2:48-58.

86. Porta R, Sanchez-Torres JM, Paz-Ares L, et al. Brain metastases from lung cancer responding to erlotinib: the importance of EGFR mutation. Eur Respir J 2011;37:624-31.

87. Togashi Y, Masago K, Masuda S, et al. Cerebrospinal fluid concentration of gefitinib and erlotinib in patients with non-small cell lung cancer. Cancer Chemother Pharmacol 2012;70:399-405.

88. Deng $\mathrm{Y}$, Feng $\mathrm{W}, \mathrm{Wu} \mathrm{J}$, et al. The concentration of erlotinib in the cerebrospinal fluid of patients with brain metastasis from non-small-cell lung cancer. Mol Clin Oncol 2014;2:116-20.

89. Togashi Y, Masago K, Fukudo M, et al. Cerebrospinal fluid concentration of erlotinib and its active metabolite OSI420 in patients with central nervous system metastases of non-small cell lung cancer. J Thorac Oncol 2010;5:950-5.

90. Yufen X, Binbin S, Wenyu C, et al. The role of EGFRTKI for leptomeningeal metastases from non-small cell lung cancer. Springerplus 2016;5:1244.

91. Hoffknecht P, Tufman A, Wehler T, et al. Efficacy of the irreversible ErbB family blocker afatinib in epidermal growth factor receptor (EGFR) tyrosine kinase inhibitor (TKI)-pretreated non-small-cell lung cancer patients with brain metastases or leptomeningeal disease. J Thorac Oncol 2015;10:156-63.

92. Ballard P, Yates JW, Yang Z, et al. Preclinical Comparison of Osimertinib with Other EGFR-TKIs in EGFR-Mutant NSCLC Brain Metastases Models, and Early Evidence of Clinical Brain Metastases Activity. Clin Cancer Res 2016;22:5130-40.

93. Varrone A, Varnäs K, Jucaite A, et al. A PET study in healthy subjects of brain exposure of 11C-labelled osimertinib - A drug intended for treatment of brain metastases in non-small cell lung cancer. J Cereb Blood Flow Metab 2020;40:799-807.

94. Kodama T, Hasegawa M, Takanashi K, et al. Antitumor activity of the selective ALK inhibitor alectinib in models of intracranial metastases. Cancer Chemother Pharmacol 
2014;74:1023-8.

95. Drizou M, Kotteas EA, Syrigos N. Treating patients with ALK-rearranged non-small-cell lung cancer: mechanisms of resistance and strategies to overcome it. Clin Transl Oncol 2017;19:658-66.

96. Chow LQ, Barlesi F, Bertino EM, et al. Results of the ASCEND-7 phase II study evaluating ALK inhibitor (ALKi) ceritinib in patients (pts) with $\mathrm{ALK}+$ non-small cell lung cancer (NSCLC) metastatic to the brain. Ann Oncol 2019;30:v602-v660.

97. Milton DT, Azzoli CG, Heelan RT, et al. A phase I/ II study of weekly high-dose erlotinib in previously treated patients with nonsmall cell lung cancer. Cancer 2006;107:1034-41.

98. Yang JCH, Kim SW, Kim DW, et al. Osimertinib in Patients With Epidermal Growth Factor Receptor Mutation-Positive Non-Small-Cell Lung Cancer and Leptomeningeal Metastases: The BLOOM Study. J Clin Oncol 2020;38:538-47.

99. MarijnVeerman GD, Hussaarts KGAM, Jansman FGA, et al. Clinical implications of food-drug interactions with small-molecule kinase inhibitors. Lancet Oncol 2020:21:e265-79.

100. Hussaarts K, Veerman GDM, Jansman FGA, et al. Clinically relevant drug interactions with multikinase inhibitors: a review. Ther Adv Med Oncol 2019;11:1758835918818347.

101. Camidge DR, Lee EQ, Lin NU, et al. Clinical trial design for systemic agents in patients with brain metastases from solid tumours: a guideline by the Response Assessment in Neuro-Oncology Brain Metastases working group. Lancet Oncol 2018;19:e20-32.

102.Lin NU, Lee EQ, Aoyama H, et al. Response assessment criteria for brain metastases: proposal from the RANO group. Lancet Oncol 2015;16:e270-8.

103. Dhermain F, Barani IJ. Complications from radiotherapy. Handb Clin Neurol 2016;134:219-34.

104.Le Rhun E, Dhermain F, Vogin G, et al. Radionecrosis after stereotactic radiotherapy for brain metastases. Expert Rev Neurother 2016;16:903-14.

105.Soon YY, Leong CN, Koh WY, et al. EGFR tyrosine kinase inhibitors versus cranial radiation therapy for EGFR mutant non-small cell lung cancer with brain metastases: a systematic review and meta-analysis. Radiother Oncol 2015;114:167-72.

106.Bokobza SM, Jiang Y, Weber AM, et al. Short-course treatment with gefitinib enhances curative potential of radiation therapy in a mouse model of human non- small cell lung cancer. Int J Radiat Oncol Biol Phys 2014;88:947-54.

107. Chinnaiyan P, Huang S, Vallabhaneni G, et al. Mechanisms of enhanced radiation response following epidermal growth factor receptor signaling inhibition by erlotinib (Tarceva). Cancer Res 2005;65:3328-35.

108. Dai Y, Wei Q, Schwager C, et al. Synergistic effects of crizotinib and radiotherapy in experimental EML4ALK fusion positive lung cancer. Radiother Oncol 2015;114:173-81.

109. Hendriks LE, Schoenmaekers J, Zindler JD, et al. Safety of cranial radiotherapy concurrent with tyrosine kinase inhibitors in non-small cell lung cancer patients: A systematic review. Cancer Treat Rev 2015;41:634-45.

110. Shukuya T, Takahashi T, Naito T, et al. Continuous EGFR-TKI administration following radiotherapy for non-small cell lung cancer patients with isolated CNS failure. Lung Cancer 2011;74:457-61.

111. Weickhardt AJ, Scheier B, Burke JM, et al. Local ablative therapy of oligoprogressive disease prolongs disease control by tyrosine kinase inhibitors in oncogene-addicted non-small-cell lung cancer. J Thorac Oncol 2012;7:1807-14.

112. Eichler AF, Chung E, Kodack DP, et al. The biology of brain metastases-translation to new therapies. Nat Rev Clin Oncol 2011;8:344-56.

113. Chamberlain MC, Baik CS, Gadi VK, et al. Systemic therapy of brain metastases: non-small cell lung cancer, breast cancer, and melanoma. Neuro Oncol 2017;19:i1-i24.

114. Maruyama R, Wataya H, Seto T, et al. Treatment after the failure of gefitinib in patients with advanced or recurrent non-small cell lung cancer. Anticancer Res 2009;29:4217-21.

115. Nishie K, Kawaguchi T, Tamiya A, et al. Epidermal growth factor receptor tyrosine kinase inhibitors beyond progressive disease: a retrospective analysis for Japanese patients with activating EGFR mutations. J Thorac Oncol 2012;7:1722-7.

116. Yap TA, Macklin-Doherty A, Popat S. Continuing EGFR inhibition beyond progression in advanced non-small cell lung cancer. Eur J Cancer 2017;70:12-21.

117.Ahn MJ, Kim DW, Cho BC, et al. Activity and safety of AZD3759 in EGFR-mutant non-small-cell lung cancer with CNS metastases (BLOOM): a phase 1, open-label, dose-escalation and dose-expansion study. Lancet Respir Med 2017;5:891-902.

118. Flippot R, Biondani P, Auclin E, et al. Activity of 
EGFR Tyrosine Kinase Inhibitors in NSCLC With Refractory Leptomeningeal Metastases. J Thorac Oncol 2019;14:1400-7.

119.Jackman DM, Cioffredi LA, Jacobs L, et al. A phase I trial of high dose gefitinib for patients with leptomeningeal metastases from non-small cell lung cancer. Oncotarget 2015;6:4527-36.

120. How J, Mann J, Laczniak AN, et al. Pulsatile Erlotinib in EGFR-Positive Non-Small-Cell Lung Cancer Patients With Leptomeningeal and Brain Metastases: Review of the Literature. Clin Lung Cancer 2017;18:354-63.

121. Kawamura T, Hata A, Takeshita J, et al. High-dose erlotinib for refractory leptomeningeal metastases after failure of standard-dose EGFR-TKIs. Cancer Chemother Pharmacol 2015;75:1261-6.

122. Wang BX, Ou W, Mao XY, et al. Impacts of EGFR

Cite this article as: Schoenmaekers JJAO, Paats MS, Dingemans AMC, Hendriks LEL. Central nervous system metastases and oligoprogression during treatment with tyrosine kinase inhibitors in oncogene-addicted non-small cell lung cancer: how to treat and when? Transl Lung Cancer Res 2020;9(6):2599-2617. doi: 10.21037/tlcr-20-459 mutation and EGFR-TKIs on incidence of brain metastases in advanced non-squamous NSCLC. Clin Neurol Neurosurg 2017;160:96-100.

123. Rosell R, Dafni U, Felip E, et al. Erlotinib and bevacizumab in patients with advanced non-small-cell lung cancer and activating EGFR mutations (BELIEF): an international, multicentre, single-arm, phase 2 trial. Lancet Respir Med 2017;5:435-44.

124.Letarte N, Bressler LR, Villano JL. Bevacizumab and central nervous system (CNS) hemorrhage. Cancer Chemother Pharmacol 2013;71:1561-5.

125.Zimmermann S, Dziadziuszko R, Peters S. Indications and limitations of chemotherapy and targeted agents in nonsmall cell lung cancer brain metastases. Cancer Treat Rev 2014;40:716-22. 